J. Dairy Sci. 92:5697-5701

doi:10.3168/jds.2009-2220

(c) American Dairy Science Association, 2009.

\title{
Technical note: The use of a telemetric system to continuously monitor ruminal temperature and to predict ruminal $\mathrm{pH}$ in cattle
}

\author{
O. AlZahal, ${ }^{*}$ M. A. Steele, ${ }^{*}$ E. V. Valdes, $†$ and B. W. McBride ${ }^{* 1}$ \\ *Department of Animal and Poultry Science, University of Guelph, N1G 2W1 Ontario, Canada \\ †Disney's Animal Kingdom, Lake Buena Vista, FL 32837
}

\begin{abstract}
The objective of this study was to compare a telemetric monitoring system to an existing in situ methodology (conventional system) of monitoring ruminal temperature and to validate its use to detect changes in ruminal $\mathrm{pH}(\mathrm{RpH})$. Four nonlactating, ruminally cannulated Holstein dairy cows $(760 \pm 30 \mathrm{~kg}$ of body weight, mean \pm standard deviation) housed in a tie-stall facility were used in the study. The experiment was conducted during the month of May and the recorded ambient temperature was $8.0 \pm 2.0^{\circ} \mathrm{C}$ (mean $\pm \mathrm{SD}$ ). The cows were fed a diet consisting of chopped mixed hay $(\mathrm{MH} ; 11.3 \%$ crude protein, $59.7 \%$ neutral detergent fiber, $17.3 \%$ nonfiber carbohydrate, $3.1 \%$ ether extract, and $11.3 \%$ ash; dry matter basis) during wk 1 and were gradually switched to a high-grain (HG) diet $(11.6 \%$ crude protein, $30.2 \%$ neutral detergent fiber, $50.7 \%$ nonfiber carbohydrate, $3.0 \%$ ether extract, and $6.0 \%$ ash; dry matter basis) during wk 2. A conventional system that utilized an indwelling electrode was used to monitor $\mathrm{RpH}$ and ruminal temperature $\left(\mathrm{RT}_{\mathrm{C}}\right)$ during $\mathrm{d} 6$ and 7 of each week. The indwelling electrode was attached to a telemetric bolus and ruminal temperature $\left(\mathrm{RT}_{\mathrm{T}}\right)$ was logged into a personal computer. The daily mean, minimum, and maximum $\mathrm{RpH}$ and duration $(\mathrm{min} / \mathrm{d})$ $\mathrm{RpH}<6.2$ were $6.39 \pm 0.04,6.10 \pm 0.05,6.66 \pm 0.03$, and $107 \pm 50$ during $\mathrm{MH}$ feeding (wk 1) and $5.84 \pm$ $0.03,5.35 \pm 0.05,6.35 \pm 0.03$, and $1,257 \pm 40$ during HG feeding (wk 2), respectively, and were different across diets (week effect). Ruminal $\mathrm{pH}$ did not decrease below 5.6, 5.8, and 6.0 during $\mathrm{MH}$ feeding; mean duration of $\mathrm{RpH}<5.6,<5.8$, and $<6.0$ during $\mathrm{HG}$ feeding was $279 \pm 149,611 \pm 139$, and $894 \pm 101$, respectively. Mean daily $\mathrm{RT}_{\mathrm{C}}$ increased from $37.5^{\circ} \mathrm{C} \pm 0.1$ in wk 1 to $38.6^{\circ} \mathrm{C} \pm 0.1$ in wk 2 ; there was also an increase from wk 1 to wk 2 in minimum and maximum daily $\mathrm{RT}_{\mathrm{C}}$ and durations $(\mathrm{min} / \mathrm{d})$ of $\mathrm{RT}_{\mathrm{C}}>38.0,>38.2,>38.4$, and $>38.6^{\circ} \mathrm{C}$. These increases were not detectable with
\end{abstract}

Received March 17, 2009.

Accepted July 21, 2009

${ }^{1}$ Corresponding author: bmcbride@uoguelph.ca the telemetric system. Ruminal temperature obtained by the conventional system was $0.68^{\circ} \mathrm{C} \pm 0.005$ lower than $\mathrm{RT}_{\mathrm{T}}$ during $\mathrm{MH}$ feeding (wk 1), whereas $\mathrm{RT}_{\mathrm{C}}$ was $0.04^{\circ} \mathrm{C} \pm 0.004$ higher than $\mathrm{RT}_{\mathrm{T}}$ during $\mathrm{HG}$ feeding (wk 2). Daily minimum $\mathrm{RpH}$ was associated with maximum daily $\mathrm{RT}_{\mathrm{C}}$ and $\mathrm{RT}_{\mathrm{T}}$ during $\mathrm{MH}$ and $\mathrm{HG}$ feeding $\left(\mathrm{R}^{2}=\right.$ 0.88 and 0.43 , respectively). There was a high association between low $\mathrm{RpH}$ and high ruminal temperature, with the highest associations being between duration $(\mathrm{min} / \mathrm{d})$ of $\mathrm{RpH}<6.0$ and duration of $\mathrm{RT}_{\mathrm{C}}>39.0^{\circ} \mathrm{C}$ $\left(\mathrm{R}^{2}=0.68\right)$ and $\mathrm{RT}_{\mathrm{T}}>39.2^{\circ} \mathrm{C}\left(\mathrm{R}^{2}=0.72\right)$. Unlike the telemetric system, the conventional system requires cow cannulation; therefore, the current study provided a noninvasive alternative for measuring ruminal temperature and the prediction of $\mathrm{RpH}$. Additional studies are needed to develop an algorithm that accounts for diet type, seasonal variation in temperature, and core body temperature to predict subacute ruminal acidosis effectively on farm.

Key words: telemetry, ruminal temperature, ruminal $\mathrm{pH}$

The ability to monitor physiological responses (e.g., temperature, fluid $\mathrm{pH}$, heart rate), which can indicate diseases in livestock, via telemetric technology has great potential to increase timely disease detection, thus improving animals' health, productivity, and welfare. The first use of telemetric technology reported in the literature was by Jacobson and MacKay (1957) to study gastrointestinal physiology. However, early systems had some disadvantages such as the short life of transmitter batteries, drifting sensors, and high cost. Advancement in sensor and battery technologies facilitated the development of more stable sensors, particularly those used for measuring body temperature (Brown-Brandl et al., 2003). The implementation of telemetric systems to monitor core body temperature in cattle has recently attracted industry attention. Research shows that ruminal temperature (RT), measured via an intraruminal telemetric sensing device (bolus), can potentially be used to monitor the health of growing cattle (Sims et al., 2008; Small et al., 2008) and for the early diagnosis of bovine respiratory disease and bovine viral diarrhea 
in cattle (Dye et al., 2007). It also has the potential to predict parturition and estrus in cattle (Prado-Cooper et al., 2008).

Additionally, our research has shown that there is a close relationship between RT and ruminal pH $(\mathbf{R p H})$, as RT is inversely related to $\mathrm{RpH}$ (AlZahal et al., 2008). It is not surprising that $\mathrm{RT}$ and $\mathrm{RpH}$ are so closely associated; ruminal fermentation produces end products such as VFA, methane, and heat (Hungate 1966). Therefore, cows receiving grain-rich diets are expected to have lower $\mathrm{RpH}$ and an elevated RT. The previous study (AlZahal et al., 2008) utilized an indwelling electrode to measure RT but which required cow cannulation. Alternatively, RT can be recorded in a noninvasive manner via a telemetric ruminal bolus administered orally and linked to an acquisition system. The objective of this study was to compare such a telemetric monitoring system to an existing in situ methodology (conventional system) of monitoring RT and validate its use to predict $\mathrm{RpH}$.

Four nonlactating, ruminally cannulated Holstein dairy cows $(760 \pm 30 \mathrm{~kg}$, mean $\pm \mathrm{SD})$ housed in a tie-stall facility at the University of Guelph, Ontario, Canada, were utilized for this study. Cows were cared for and handled in accordance with the Canadian Council on Animal Care regulations (CCAC, 1993). The University of Guelph Animal Care Committee approved the use of the cows for this experiment. Cows' rectal temperature was $38.3 \pm 0.4^{\circ} \mathrm{C}$ (mean $\pm \mathrm{SD}$ ) at $0700 \mathrm{~h}$ at the beginning of the study, which is considered within the normal physiological range (Rebhun, 1995). The study was conducted from May 15 through May 30, 2008.

During $\mathrm{d} 1$ to 7 , cows were fed a diet consisting of chopped mixed hay (MH; $11.3 \% \mathrm{CP}, 59.7 \% \mathrm{NDF}$, $17.3 \%$ NFC, $3.1 \%$ ether extract, and $11.3 \%$ ash; DM basis). During d 8 to 12 , the amount of hay was gradually reduced and substituted with mixed-grain pellets (40\% barley, 40\% wheat, and 20\% corn). During d 13 and 14 , cows received a high-grain $(\mathbf{H G})$ diet consisting of $65 \%$ mixed-grain pellets and $35 \%$ mixed hay $(11.6 \%$ $\mathrm{CP}, 30.2 \% \mathrm{NDF}, 50.7 \% \mathrm{NFC}, 3.0 \%$ ether extract, and $6.0 \%$ ash; DM basis). The mixed hay was divided into 2 equal allotments $(0800$ and $1600 \mathrm{~h})$ throughout the experiment and the amount of pellets was divided into 3 equal allotments $(0800,1200$, and $1600 \mathrm{~h})$ during wk 2. The amount of feed offered was $1.4 \%$ of BW during wk 1 and $1.7 \%$ of BW during wk 2. The amount of feed offered was approximately similar to the expected DM intake for this group of cows; however, this approach facilitated the calculation of feed allotments and the reduction of orts. Water was offered at all times and supplemental vitamins and minerals were offered at $0.02 \%$ of BW per $\mathrm{d}$.
The conventional in situ method used to continuously monitor RpH and RT was described by AlZahal et al. (2007). Briefly, the system was composed of an indwelling electrode equipped with $\mathrm{pH}$ and temperature sensors and attached to a $1.0-\mathrm{kg}$ weight to ensure that the electrode resided in the ventral sac. The electrode was connected to a data logger that was enclosed in a box mounted on the animal's back. The system was set to record both $\mathrm{pH}$ and temperature every minute during $\mathrm{MH}$ feeding (d 6 and 7 ) and during HG feeding (d 13 and 14). Ruminal temperature was also recorded using a telemetric acquisition system (SmartStock LLC, Pawnee, OK), which was composed of the following: a telemetric ruminal bolus $(3 \mathrm{~cm}$ in diameter and $8.5 \mathrm{~cm}$ in height, $120 \mathrm{~g}$ in weight), an antenna, a barn receiver unit, a base receiver unit, and a personal computer equipped with a software program for data logging. Ruminal temperature measurements were broadcasted through a radio frequency $(0.3-3.0 \mathrm{GHz})$ from the bolus to the barn receiver unit through the antenna that was within $100 \mathrm{~m}$ of the cows. The signal was then transmitted (0.9 $\mathrm{GHz}$ ) from the barn receiver unit to the base receiver unit (located within a 2.5 - $\mathrm{km}$ range), which was connected via a cable to the personal computer. The bolus was designed for oral administration using a bolus gun. However, for the purpose of this experiment, the bolus was placed in a mesh bag $(20 \times 15 \mathrm{~cm}$, pore size $=2$ $\mathrm{mm}$ ) and attached to the conventional electrode. This was done in order to localize the position of the bolus in the ventral rumen. The bolus was originally designed to transmit once per hour. Each transmission contained 12 to 48 readings (i.e., the current and previous 11 to 47 recordings) in order to minimize the loss of data resulting from lost transmissions. The battery life expectancy of the bolus is approximately 4 to 5 yr. For the purpose of validating the telemetric system and to be consistent with previous work, the bolus was customized to transmit every minute and each transmission included 12 recordings.

Ruminal temperature recordings obtained by the conventional system $\left(\mathbf{R T}_{\mathbf{C}}\right)$ were synchronized by the minute with ruminal temperature recordings obtained by the telemetric bolus $\left(\mathbf{R T}_{\mathbf{T}}\right)$ using the merge function of SAS (SAS Institute, 2004). A paired $t$-test was conducted using SAS on the difference between each pair of observations $\left(\mathrm{RT}_{\mathrm{T}}-\mathrm{RT}_{\mathrm{C}}\right)$ for each minute.

Mean, minimum, and maximum daily $\mathrm{RpH}, \mathrm{RT}_{\mathrm{C}}$, and $\mathrm{RT}_{\mathrm{T}}$ were calculated from all available observations using PROC MEANS of SAS (SAS Institute, 2004). Although the use of data minima and maxima is beneficial in describing the range of data change, it does not indicate the magnitude of this change. Therefore, the duration $(\mathrm{min} / \mathrm{d})$ that ruminal fluid $\mathrm{pH}$ was below a given threshold (i.e., 5.6, 5.8, 6.0, and so on) 
was computed to describe the magnitude of ruminal pH depression. AlZahal et al. (2008) utilized the same approach to describe the magnitude of RT elevation (i.e., time above a specific RT threshold) in the rumen. The durations that $\mathrm{RpH}$ measurements were below a given $\mathrm{pH}$ threshold and $\mathrm{RT}_{\mathrm{C}}$ and $\mathrm{RT}_{\mathrm{T}}$ recordings were above a given temperature threshold were calculated for each day of recording using PROC MEANS of SAS (SAS Institute, 2004). To determine which $\mathrm{pH}$ and temperature thresholds were suitable for performing statistical analysis across treatment groups, normality statistics was performed on the duration data as described by AlZahal et al. (2009). For example, RpH data showed positive skewness at $\mathrm{pH} 5.6,5.8$, and 6.0 during $\mathrm{MH}$ feeding; therefore, 6.2 proved the most appropriate threshold at which an ANOVA test could be reliably conducted across treatments. The difference in overall performance between the conventional and telemetric systems was calculated from the daily values using PROC MIXED of SAS (SAS Institute, 2004). The model included the fixed effects of method, week, and their interaction and accounted for repeated measures. Multiple comparisons of treatments' least squares means were conducted using the Tukey test (Tukey, 1991). Ruminal $\mathrm{pH}$ parameters were analyzed similarly to the previous model using PROC MIXED of SAS (SAS Institute, 2004); the model included the fixed effect of week. Analysis of the association between $\mathrm{RpH}$ and temperature $\left(\mathrm{RT}_{\mathrm{C}}\right.$ or $\left.\mathrm{RT}_{\mathrm{T}}\right)$ was conducted using PROC GLM of SAS (SAS Institute, 2004).

The daily mean, minimum, and maximum $\mathrm{RpH}$, and duration $(\mathrm{min} / \mathrm{d})$ of $\mathrm{RpH}<6.2$ were $6.39 \pm 0.04,6.10$ $\pm 0.05,6.66 \pm 0.03$, and $107 \pm 50$, respectively, during MH feeding (wk 1) and $5.84 \pm 0.03,5.35 \pm 0.05,6.35$ \pm 0.03 , and $1,257 \pm 40$, respectively, during HG feeding (wk 2) and were different across diets (week effect; $P$ $<0.05$ ). Ruminal $\mathrm{pH}$ did not decrease below 5.6, 5.8, or 6.0 during $\mathrm{MH}$ feeding, and duration of $\mathrm{RpH}<5.6$, $<5.8$, and $<6.0$ was $279 \pm 149,611 \pm 139$, and $894 \pm$ 101 ( $\mathrm{min} / \mathrm{d})$, respectively, during HG feeding.

The average daily number of $\mathrm{RpH}$ and $\mathrm{RT}_{\mathrm{C}}$ recordings obtained by the conventional system was 1,418 \pm 43 (mean $\pm \mathrm{SD} ; 98 \%$ of expected) whereas the average daily number of $\mathrm{RT}_{\mathrm{T}}$ was $1,154 \pm 137$ (80\% of expected). The lower number of observations acquired by the telemetric system was likely a result of the high frequency of recording (1 per min) or the blockage of transmissions by barn structures.

The difference between pairs of readings $\left(\mathrm{RT}_{\mathrm{T}}-\right.$ $\left.\mathrm{RT}_{\mathrm{C}}\right)$ was $+0.68 \pm 0.005(P<0.05 ; \mathrm{n}=8,760$ pairs $)$ during $\mathrm{MH}$ feeding and $-0.04 \pm 0.004(P<0.05$; n $=9,562$ pairs) during $\mathrm{HG}$ feeding. The daily means of the RT parameters are presented in Table 1 . There was a significant interaction between week and method; therefore, results interpretation was conducted by week. During wk 1, most temperature variables measured by the telemetric system were greater than those measured by the conventional system. During wk 2 , there was no difference across the RT variables between methods of measurement $(P>0.05$; Table 1). Daily mean, minimum, and maximum $\mathrm{RT}_{\mathrm{C}}$ and durations $(\mathrm{min} / \mathrm{d}$ ) of $\mathrm{RT}_{\mathrm{C}}>38.0,>38.2,>38.4$, and $>38.6^{\circ} \mathrm{C}$ increased from wk 1 to wk 2 (Table $1 ; P<0.05$ ). There were no changes in any $\mathrm{RT}_{\mathrm{T}}$ parameter from wk 1 to wk $2(P$ $>0.05$; Table 1$)$. The reason for the higher values of $\mathrm{RT}_{\mathrm{T}}$ compared with $\mathrm{RT}_{\mathrm{C}}$, and thus the failure to detect an increase in $\mathrm{RT}_{\mathrm{T}}$ with $\mathrm{HG}$ feeding, is not clearly understood. During high-forage feeding, stratification of digesta is distinct and becomes less notable with increasing concentrate:forage ratio (Tafaj et al., 2004). The materials in the top stratum of the digesta are freshly ingested and are more actively fermenting than those in the middle and bottom strata of the rumen (Tafaj et al., 2004). Therefore, ruminal temperature may vary from $40^{\circ} \mathrm{C}$ at the top of the rumen to $38.5^{\circ} \mathrm{C}$ at the bottom of the rumen (Dale et al., 1954). Additionally, Beatty et al. (2008) reported a ruminal temperature of approximately $40^{\circ} \mathrm{C}$ in the dorsal sac of the rumen for heifers fed pelleted feed. They suggested that rumen temperature under this feeding condition was homogeneous as a result of a lack of clear stratification of digesta within the rumen. In the current experiment, the conventional electrode was placed in the ventral sac of the rumen and anchored with a 1-kg weight whereas the telemetric bolus relied on its own weight (120 g) and was attached to the conventional electrode via a mesh bag in order to maintain its position within the rumen. Therefore, a spatial separation between the 2 measurement devices during high-roughage feeding could not be ruled out.

High daily maximum $\mathrm{RT}_{\mathrm{C}}$ and $\mathrm{RT}_{\mathrm{T}}$ were associated with low daily minimum $\mathrm{RpH}$ during both wk 1 and 2 $\left(\right.$ minimum $\mathrm{RpH}=27.3-0.56 \times$ maximum $\mathrm{RT}_{\mathrm{C}}, \mathrm{R}^{2}=$ $0.87, P<0.05$; minimum $\mathrm{RpH}=40.86-0.90 \times$ maximum $\left.\mathrm{RT}_{\mathrm{T}}, \mathrm{R}^{2}=0.43, P<0.05\right)$. Low $\mathrm{RpH}$ during $\mathrm{HG}$ feeding, described by longer durations $(\mathrm{min} / \mathrm{d})$ of $\mathrm{RpH}$ $<5.6,<5.8$, and $<6.0$, was associated with an elevated RT obtained via both the telemetric and conventional systems. Low $\mathrm{RpH}$ was associated with durations $(\mathrm{min} / \mathrm{d})$ of $\mathrm{RT}_{\mathrm{C}}>38.6,>38.8,>39.0$, and $>39.2^{\circ} \mathrm{C}(P$ $<0.05)$, with the highest association being between the duration of $\mathrm{RpH}<6.0$ and the duration of $\mathrm{RT}_{\mathrm{C}}>39.0^{\circ} \mathrm{C}$ $\left[\mathrm{RpH}<6.0(\mathrm{~min} / \mathrm{d})=802+0.63 \times \mathrm{RT}_{\mathrm{C}}>39.0^{\circ} \mathrm{C}, \mathrm{R}^{2}\right.$ $=0.68, P<0.05]$. Low $\mathrm{RpH}$ was associated with the duration $(\mathrm{min} / \mathrm{d})$ of $\mathrm{RT}_{\mathrm{T}}>39.2^{\circ} \mathrm{C}$ only $(P<0.05)$, with the highest association being between the duration of $\mathrm{RpH}<6.0$ and the duration of $\mathrm{RT}_{\mathrm{T}}>39.2^{\circ} \mathrm{C}[\mathrm{RpH}<6.0$ $(\min / \mathrm{d})=769+1.46 \times \mathrm{RT}_{\mathrm{T}}>39.2^{\circ} \mathrm{C}, \mathrm{R}^{2}=0.72, P<$ 
5700

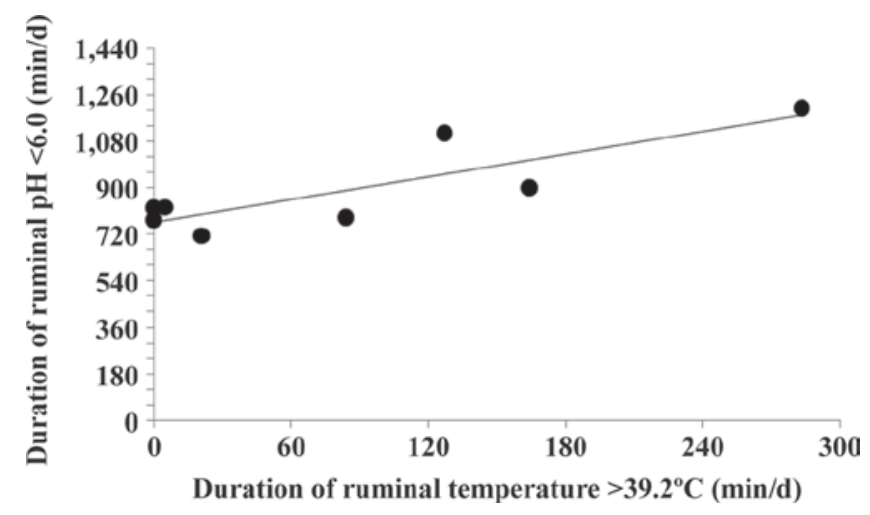

Figure 1. The association between daily means of durations (min/d) of ruminal $\mathrm{pH}<6.0$ using an established in situ method and duration $\left(\mathrm{min} / \mathrm{d}\right.$ ) of ruminal temperature $>39.2^{\circ} \mathrm{C}$ using a telemetric bolus system during feeding of the high-grain diet (wk 2) [Ruminal $\mathrm{pH}<6.0(\mathrm{~min} / \mathrm{d})=769+1.46 \times$ ruminal temperature $>39.2^{\circ} \mathrm{C}, \mathrm{R}^{2}$ $=0.72, P<0.05]$.

0.05; Figure 1]. The data demonstrated, in agreement with our previous study (AlZahal et al., 2008), that accelerated ruminal fermentation during grain feeding was associated with a reduction in ruminal $\mathrm{pH}$ and an elevation in ruminal temperature. This is understandable because VFA, lactate, and temperature are byproducts of bacterial ruminal fermentation (Hungate, 1966). Variations in $\mathrm{RpH}$ were explained mostly by variations in RT; for example, Figure 1 shows that the duration ( $\mathrm{min} / \mathrm{d}$ ) of $\mathrm{RpH}<6.0$ can be computed using the duration of RT $>39.2^{\circ} \mathrm{C}$. This concept has the potential to be further developed into an on-farm method for predicting ruminal $\mathrm{pH}$ in lactating cows during subacute ruminal acidosis (SARA).
The differences between $\mathrm{RT}_{\mathrm{C}}$ and $\mathrm{RT}_{\mathrm{T}}$ in their relation to $\mathrm{RpH}$ during $\mathrm{HG}$ feeding could be partially explained by the lower sensitivity of the telemetric bolus to small changes in ruminal temperature. The reading resolution for the telemetric bolus was $0.28^{\circ} \mathrm{C}$ compared with only $0.01^{\circ} \mathrm{C}$ for the conventional system. Although the telemetric bolus was not able to detect a significant increase in RT between wk 1 and wk 2 (MH and HG feeding) compared with the conventional system, results showed an improved performance during wk 2 (HG feeding). Furthermore, the magnitude of $\mathrm{RpH}$ depression during wk 2 was explained by the extent of the elevation in both $\mathrm{RT}_{\mathrm{C}}$ and $\mathrm{RT}_{\mathrm{T}}$.

The association between $\mathrm{RpH}$ and RT was in agreement with a previous study (AlZahal et al., 2008). Nonetheless, RT values reported during wk 2 (HG feeding) in the current experiment were lower than RT values reported in the previous study (AlZahal et al. 2008). The cows in AlZahal et al. (2008) were lactating and their DMI was 2-fold the DMI of the nonlactating cows in the current experiment. This suggests that the amount of heat produced in the rumen is related not only to the type of feed but also to the amount of feed fermented within the rumen.

It is important to note that normal core body temperature has been reported to range from 38.0 to $39.1^{\circ} \mathrm{C}$; thus, cows with core body temperature exceeding $39.1^{\circ} \mathrm{C}$ were defined as febrile or abnormal (Rebhun, 1995). The cows used in this study were nonfebrile at the initiation of the study and no health issues were diagnosed during the experiment. However, both $\mathrm{RT}_{\mathrm{C}}$ and $\mathrm{RT}_{\mathrm{T}}$ were $>39.2^{\circ} \mathrm{C}$ for $75 \pm 35$ and $90 \pm 35 \mathrm{~min} / \mathrm{d}$, respectively, with maximum RT ranging from 39.0 to $40.0^{\circ} \mathrm{C}$. Therefore, the use of RT as a measure of core

Table 1. Least squares means for ruminal temperature characteristics obtained by either a conventional method or a telemetric monitoring system ${ }^{1}$

\begin{tabular}{|c|c|c|c|c|c|c|c|c|}
\hline \multirow[b]{2}{*}{ Item } & \multicolumn{2}{|c|}{ Conventional $^{2}$} & \multicolumn{2}{|c|}{ Telemetric $^{3}$} & \multirow[b]{2}{*}{ SE } & \multicolumn{3}{|c|}{$P$-value } \\
\hline & Wk 1 & Wk 2 & Wk 1 & Wk 2 & & Method & Week & Method $\times$ week \\
\hline Mean $\left({ }^{\circ} \mathrm{C}\right)$ & $37.5^{\mathrm{a}}$ & $38.6^{\mathrm{b}}$ & $38.2^{\mathrm{b}}$ & $38.5^{\mathrm{b}}$ & 0.1 & 0.02 & $<0.01$ & 0.02 \\
\hline Maximum $\left({ }^{\circ} \mathrm{C}\right)$ & $38.3^{\mathrm{a}}$ & $39.4^{\mathrm{b}}$ & $39.0^{\mathrm{b}}$ & $39.3^{\mathrm{b}}$ & 0.1 & 0.05 & $<0.01$ & 0.01 \\
\hline Minimum $\left({ }^{\circ} \mathrm{C}\right)$ & $35.4^{\mathrm{a}}$ & $37.1^{\mathrm{b}}$ & $36.5^{\mathrm{b}}$ & $37.5^{\mathrm{b}}$ & 0.2 & 0.01 & $<0.01$ & 0.19 \\
\hline \multicolumn{9}{|l|}{ Duration $^{4}(\min / \mathrm{d})$} \\
\hline$>38.0^{\circ} \mathrm{C}$ & $265^{\mathrm{a}}$ & $1,289^{\mathrm{b}}$ & $901^{\mathrm{b}}$ & $1,144^{\mathrm{b}}$ & 96 & 0.02 & $<0.01$ & $<0.01$ \\
\hline$>38.2^{\circ} \mathrm{C}$ & $223^{\mathrm{a}}$ & $1,228^{\mathrm{b}}$ & $678^{\mathrm{ac}}$ & $1,029^{\mathrm{bc}}$ & 118 & 0.29 & $<0.01$ & 0.01 \\
\hline$>38.4^{\circ} \mathrm{C}$ & $95^{\mathrm{a}}$ & $1,005^{\mathrm{b}}$ & $535^{\mathrm{ab}}$ & $811^{\mathrm{b}}$ & 147 & 0.42 & $<0.01$ & 0.05 \\
\hline$>38.6^{\circ} \mathrm{C}$ & $20^{\mathrm{a}}$ & $677^{\mathrm{b}}$ & $223^{\mathrm{ab}}$ & $575^{\mathrm{ab}}$ & 141 & 0.73 & $<0.01$ & 0.30 \\
\hline
\end{tabular}

${ }^{a-c}$ Means within a row with the same superscript letter are not significantly different.

${ }^{1}$ Ruminal temperature was recorded on d 6 and 7 (wk 1) and d 13 and 14 (wk 2) every minute. During wk 1, cows were fed $100 \%$ chopped mixed hay, then gradually acclimated during wk 2 to a $35 \%$ hay and $65 \%$ grain diet.

${ }^{2}$ As described by AlZahal et al. (2007).

${ }^{3}$ Manufactured by SmartStock LLC (Pawnee, OK).

${ }^{4}$ Duration $=$ length of time ruminal temperature was above a given temperature threshold . 
body temperature, hence as an indication of fever, without taking into account type of diet or the possibility of SARA may be misleading. Heat stress has been shown to increase core body temperature in dairy cows exceeding 39.0 to $40.0^{\circ} \mathrm{C}$ (Rhoads et al., 2009); nonetheless, the current study was conducted under thermoneutral conditions and the increase in RT was believed to be a result of SARA only. The effect of seasonal variation in ambient temperature on the relationship between $\mathrm{RT}$ and $\mathrm{RpH}$ is not yet investigated. The mean daily air temperature $\left(8^{\circ} \mathrm{C} \pm 2\right.$, mean $\left.\pm \mathrm{SD}\right)$ was consistent throughout the current study.

In conclusion, the current study provides a noninvasive telemetric alternative that does not require cow cannulations in order to measure ruminal temperature and thus predict ruminal $\mathrm{pH}$. Further improvement in the response of the current telemetric bolus to subtle changes in temperature, such as those encountered during $\mathrm{pH}$ depression, is needed. Further investigations, such as using roaming boluses within the rumen, are needed in order to determine the effect of diet type on rumen temperature. Also, studies are needed to develop an algorithm that accounts for diet type, seasonal variation in temperature, and core body temperature to predict SARA effectively on farm.

\section{ACKNOWLEDGMENTS}

We acknowledge the continued support received from Dairy Farmers of Canada and Natural Sciences and Engineering Research Council of Canada (B. W. McBride).

\section{REFERENCES}

AlZahal, O., E. Kebreab, J. France, M. Froetschel, and B. W. McBride. 2008. Ruminal $\mathrm{pH}$ may aid in the prediction of subacute ruminal acidosis. J. Dairy Sci. 91:202-207.

AlZahal, O., B. Rustomo, N. E. Odongo, T. F. Duffield, and B. W McBride. 2007. Technical note: A system for continuous recording of ruminal pH in cattle. J. Anim. Sci. 85:213-217.
AlZahal, O., G. Vandervoort, and B. W. McBride. 2009. A statistical methodology for the analysis of continuous measurements of ruminal pH. Can. J. Anim. Sci. 89:140. (Abstr.)

Beatty, D. T., A. Barnes, E. Taylor, and S. K. Maloney. 2008. Do changes in feed intake or ambient temperature cause changes in cattle rumen temperature relative to core temperature? J. Therm. Biol. 33:12-19.

Brown-Brandl, T. M., T. Yanagari Jr., H. Xin, R. S. Gates, R. A. Bucklin, and G. R. Ross. 2003. A new telemetry system for measuring core body temperature in livestock and poultry. Appl. Eng. Agric. 19:583-589.

Canadian Council on Animal Care. 1993. The Guide to the Care and Use of Experimental Animals. Canadian Council on Animal Care, Ottawa, Canada.

Dale, H. E., R. E. Stewart, and S. Brody. 1954. Rumen temperature. 1. Temperature gradients during feeding and fasting. Cornell Vet. 44:368-374.

Dye, T. K., C. J. Richards, L. O. Burciaga-Robles, C. R. Krehbiel, and D. L. Step. 2007. Efficacy of rumen temperature boluses for health monitoring. J. Dairy Sci. 90(Suppl. 1):255. (Abstr.)

Hungate, R. E. 1966. The Rumen and Its Microbes. Academic Press, New York, NY.

Jacobson, B., and R. S. MacKay. 1957. A pH-endoradiosonde. Lancet $227: 1224$.

Prado-Cooper, M. J., N. M. Long, E. C. Wright, C. J. Richards, and P. Wettermann. 2008. Relationship of rumen temperature of beef cows to parturition and estrus. J. Anim. Sci. 86(E-Suppl. 3):20. (Abstr.)

Rebhun, W. C. 1995. Diseases of Dairy Cattle. Williams \& Wilkins, Baltimore, MD.

Rhoads, M. L., R. P. Rhoads, M. J. VanBaale, R. J. Collier, S. R. Sanders, W. J. Weber, B. A. Crooker, and L. H. Baumgard. 2009. Effects of heat stress and plane of nutrition on lactating Holstein cows: I. Production, metabolism, and aspects of circulating somatotropin. J. Dairy Sci. 92:1986-1997.

SAS Institute. 2004. SAS/STAT 9.1 User's Guide. SAS Institute Inc. Cary, NC.

Sims, E., T. K. Dye, B. P. Holland, L. O. Burciaga-Robles, D. L. Step, R. W. Fulton, C. R. Krehbiel, and C. J. Richards. 2008. Rumen temperature monitoring for determination of health. J. Anim. Sci. 86(E-Suppl. 3):115. (Abstr.)

Small, J. A., A. D. Kennedy, and S. H. Kahane. 2008. Core body temperature monitoring with passive transponder boluses in beef heifers. Can. J. Anim. Sci. 88:225-235.

Tafaj, M., B. Junck, A. Maulbetsch, H. Steingass, H.-P. Piepho, and W. Drochner. 2004. Digesta characteristics of dorsal, middle and ventral rumen of cows fed with different hay qualities and concentrate levels. Arch. Anim. Nutr. 58:325-342.

Tukey, J. 1991. The philosophy of multiple comparisons. Stat. Sci. $6: 100-116$. 